\title{
Bio-Efficacy of Early Post and Post Emergent Application of Tembotrione on Nutrient Removal by Crop and Weeds in Spring Maize (Zea mays L.) Under Irrigated Sub-Tropical Shiwalik Foothill Conditions of J \& K, India
}

\author{
Parveen Akhtar*, Anil Kumar, Jai Kumar, Neetu Sharma, Lobzang Stanzen, \\ Ashu Sharma and Amit Mahajan
}

Department of Agronomy, Sher-e-Kashmir University of Agriculture Science and Technology, FOA Chatha, Jammu-180009, India

*Corresponding author

\begin{tabular}{|c|c|}
\hline & A B S T R A C T \\
\hline Keywords & \multirow{4}{*}{$\begin{array}{l}\text { A field experiment was conducted at Jammu, during the spring season } 2013 \\
\text { to evaluate the efficacy of tembotrione ( } 42 \% \text { SC) on nutrient removal by } \\
\text { crop and weeds in spring maize. The experimental field was highly infested } \\
\text { with Cyperus rotundus, Cynodon dactylon, Phyllanthus niruri and Digitria } \\
\text { sanguinalis. Post emergence application of tembotrione @ } 120 \mathrm{~g} / \text { ha at } 15 \\
\text { DAS resulted in significantly highest NPK uptake by grain and stover of } \\
\text { crop and lowest NPK uptake by weeds which was at par with pos } \\
\text { emergence application of tembotrione @ } 120 \mathrm{~g} / \mathrm{ha} \text { at } 30 \mathrm{DAS} \text { and two hand } \\
\text { weeding at } 15 \text { and } 30 \mathrm{DAS} \text {. }\end{array}$} \\
\hline $\begin{array}{l}\text { Spring } \\
\text { Maize, } \\
\text { Uptake, Weeds. }\end{array}$ & \\
\hline Article Info & \\
\hline $\begin{array}{l}\text { Accepted: } \\
\text { 14 May } 2017 \\
\text { Available Online: } \\
\text { 10 June } 2017\end{array}$ & \\
\hline
\end{tabular}

\section{Introduction}

Maize occupies pride place in India both as food and feed for animals and is an important cereal crop after rice and wheat. By virtue of it's having extremely low photo-respiration and distinct leaf anatomy, it has got highest production potential among all the cereals. It is the third important crop of the world after rice and wheat and occupies prominent place in world agriculture due to its wide spread cultivation in tropics, sub-tropics and temperate regions of the world. Maize cultivation is gaining popularity in spring season because usually it gives more production as compared to kharif maize. Spring maize is safe from insect-pest attack. It can be grown in area where adequate irrigation facilities are available. The area under maize cultivation is meager in the country and the low productivity can be attributed to several factors and all but one factor amongst those has poor weed management. Infestation of weeds removes nutrients from the soil thus, adversely affects the production of crop. Weeds increase cost of cultivation and deplete the resource base. Weeds constitute a serious limiting factor in successful crop husbandry and are responsible for marked losses ranging from (28-100 \%) in the yields of various crops (Pandey et al., 2001). Among the various pests, weeds 
competes with crop plants for nutrients, water, sunlight and space during entire vegetative and early reproductive stages of maize, transpire lot of valuable conserved moisture and absorb large quantities of nutrients from the soil and their relative density plays significant role in reducing the yield of crop. Weeds usually absorb mineral nutrients faster than many crop plants and accumulate them in their tissues in relatively larger amount. Luxuriant growth of weeds competed dominantly with the crop plants for nutrients (Mundra et al., 2002).

In order to achieve enhanced crop production and higher benefits from applied inputs, weeds must be kept under check by any of the safe and effective means. Uses of preemergent and post-emergent herbicides are more effective weapons in tackling weed menace and thereby nutrient removal by them. As the weeds interfere during the growth of the crop, post emergence herbicides may help in avoiding the problem of weeds at later stages. But there was no post emergence herbicides still available in market, unfortunately if in any case farmer miss the application of pre-emergent herbicides then there was no alternative for him to control the weeds emerging in later stages, now a post emergence herbicide came into existence i.e. Tembotrione, a new post emergent broad spectrum systemic, pigment synthesis inhibitor herbicide, inhibits 4-HPPD enzyme. Tembotrione is reported to remain active in the soil throughout the growing season, offering control of grass and broadleaf weeds until corn canopy closure (Almsick et al., 2009). Managing weeds through pre emergence and post emergence herbicides could be an ideal means for controlling the weeds in view of their economics and effectiveness in maize and attributed to higher weed-control efficiency resulting in more favorable environment for growth and development of crop plants apparently due to lesser weed competition which led to increased growth of crop and thereby increase in nutrient uptake by improving the leaf area, dry matter accumulation leading to better yield attributes and accumulation of higher amounts of nutrients in maize grains (Mundra et al., 2002). Keeping in view the above facts, the present study works out nutrient removal by crop and weeds by early post and post emergent application of tembotrione in spring maize (Zea mays L.) under irrigated subtropical shiwalik foothill conditions of $\mathrm{J} \& \mathrm{~K}$.

\section{Materials and Methods}

The field experiment was carried out during the spring season of 2013 at the Research Farm of Division of Agronomy, Sher-eKashmir University of Agricultural Sciences and Technology of Jammu which is situated at $320-40^{\prime} \mathrm{N}$ latitude and $740-58^{\prime} \mathrm{E}$ longitude with an altitude of $332 \mathrm{~m}$ above mean sea level. The experiment was laid out in randomized block design with eleven treatments and three replications. The treatments consisted of tembotrione@110 g/ha at 15 DAS, tembotrione @ $110 \mathrm{~g} / \mathrm{ha}$ at 30 DAS, tembotrione @ $120 \mathrm{~g} / \mathrm{ha}$ at $15 \mathrm{DAS}$, tembotrione @ $120 \mathrm{~g} / \mathrm{ha}$ at $30 \mathrm{DAS}$, tembotrione@31 g/ha + atrazine @370g/ha at 15 DAS, atrazine @ $1 \mathrm{~kg} / \mathrm{ha}$ pre emergence, pendimethalin @ $1 \mathrm{~kg} / \mathrm{ha}$ pre emergence, halosulfuron methyl @ 135 g/ha at 15 DAS, 2 hand weedings at 15 DAS and 30 DAS, weedy check and weed free.

Spring maize crop variety 'JH-3459' was sown on 29th march, 2013 in plots of size $4.8 \mathrm{~m} \times 3.0 \mathrm{~m}$. Herbicides were applied with the help of knapsack sprayer fitted with flat fan T-jet nozzle using a spray volume of $500 \mathrm{l} / \mathrm{ha}$. Pre emergence applications of atrazine@1 $\mathrm{kg} / \mathrm{ha}$ and pendimethalin @ $1 \mathrm{~kg} / \mathrm{ha}$ were done after 24 hours of sowing of spring maize crop and tembotrione @ $110 \mathrm{~g} / \mathrm{ha}$, tembotrione@120 g/ ha, tembotrione@31 
g/ha+ atrazine @ 370 g/ha, halosulfuron methyl @135 g/ha were applied after 15 days of sowing as early post emergence application whereas, post emergence application of tembotrione@110 g/ha and tembotrione @ $120 \mathrm{~g} / \mathrm{ha}$ was done 30 days after sowing. In weed free plots weeds were not allowed to grow and hand weeding was done as and when weeds emerged. Observations on weeds were recorded with the help of quadrate $0.5 \mathrm{~m}$ $\times 0.5 \mathrm{~m}$ placed randomly at 2 different locations in each plots to assess weed flora at 30, 60, 90DAS and at harvest. The data on weeds were subjected to square root transformation $(\sqrt{ } \mathrm{x}+1)$ to normalize their distribution. The number of weeds species were counted and expressed in number $/ \mathrm{m} 2$ and dry weight of total weed species was recorded after drying and expressed in $\mathrm{g} / \mathrm{m} 2$. Observations for yield and yield attributing characters were recorded after the harvest of crop. Weed indices like weed-control efficiency was calculated by using the formulae suggested by Mishra and Mishra (1997) and weed index was calculated by using the formulae suggested by Raju (1998). The uptake of major nutrients in grain, stover and weed samples were worked out by multiplying per cent nutrient content with their respective dry matter accumulation at harvest.

\section{Results and Discussion}

\section{Soil status after the harvest of crop}

\section{Change in pH, EC and OC}

The soil chemical parameters after harvest of crop did not show much of variations and thus failed to show any significant difference among various treatments (Table 1). The value of $\mathrm{pH}, \mathrm{EC}$ and $\mathrm{OC}$ obtained after harvesting of spring maize crop ranged from 7.37 to $7.41,0.19$ to $0.20 \mathrm{dS} / \mathrm{m}$ and 0.35 to 0.37 per cent, respectively under different weed management practices.

\section{Available N, P and K}

Among the weed control treatments the available $\mathrm{N}, \mathrm{P}$ and $\mathrm{K}$ content of soil after harvest of spring maize crop were not significantly influenced by weed management treatments (Table 1). Amongst the weed management treatments, highest value of NPK contents was recorded under weedy check plots as compared to rest of the plots. This might have happened due to addition of more weeds and crop root and shoot biomass that remained in the soil which was utilized by microorganisms leading to increase in mineralization process. Enhanced nutrient availability under weedy check condition can also be ascribed to another possible reason that the total uptake by crops in weedy check treatment remained lower as compared to other weed management treatments due to competition imposed by weeds and crops.

\section{Uptake studies}

\section{N, P and K uptake by grain of spring maize}

Nutrient uptake by grain in spring maize was greatly influenced by weed management treatments (Table 2). There was a profound increase in nutrient (NPK) uptake by maize grains due to weed management treatments as compared to weedy check plots. Among the weed management treatments, significantly highest NPK uptake by maize grains was recorded in the weed free plot over rest of the plots. Amongst the herbicidal treatments, significantly higher NPK uptake in grains was recorded with the post emergence application of tembotrione@120 g/ha at 15 DAS which was found to be at par with post emergence application of tembotrione @ $110 \mathrm{~g} / \mathrm{ha} 15$ DAS and 2 Hand weeding at 15 and 30 DAS. The possible reason for beneficial effect could possibly be attributed to higher weed-control efficiency with these treatments resulting in more favorable environment for growth and development of crop plants apparently due to 
lesser weed competition which led to increased growth of crop and thereby increase in nutrient uptake by improving the leaf area, dry matter accumulation leading to better yield attributes and accumulation of higher amounts of nutrients in maize grains. Similar findings were reported by Angiras and Singh (1989), Sreenivas and Satyanarayana (1996) and Mundra et al., (2002).

Table.1 Effect of weed management practices on fertility status of soil fertility changes after the completion of experiment

\begin{tabular}{|l|c|c|c|c|c|c|}
\hline & $\mathrm{pH}$ & $\begin{array}{c}\mathrm{EC} \\
(\mathrm{dS} / \mathrm{m})\end{array}$ & $\begin{array}{c}\mathrm{O} . \mathrm{C} \\
(\%)\end{array}$ & $\begin{array}{c}\mathrm{N} \\
(\mathrm{kg} / \mathrm{ha})\end{array}$ & $\begin{array}{c}\mathrm{P} \\
(\mathrm{kg} / \mathrm{ha})\end{array}$ & $\begin{array}{c}\mathrm{K} \\
(\mathrm{kg} / \mathrm{ha})\end{array}$ \\
\hline Treatments & & & & & & \\
\hline Tembotrione @ 110 g/ha at 15 DAS & 7.38 & 0.20 & 0.35 & 234.1 & 10.09 & 140.2 \\
\hline Tembotrione @ 110 g/ha at 30 DAS & 7.38 & 0.20 & 0.35 & 234.1 & 10.13 & 140.2 \\
\hline Tembotrione @ 120 g/ha at 15 DAS & 7.37 & 0.20 & 0.35 & 233.1 & 10.02 & 140.1 \\
\hline Tembotrione @ 120 g/ha at 30 DAS & 7.37 & 0.20 & 0.35 & 233.2 & 10.04 & 140.1 \\
\hline $\begin{array}{l}\text { Tembotrione @ 31 g/ha + atrazine } \\
\text { @ 370 g/ha at 15 DAS }\end{array}$ & 7.39 & 0.19 & 0.36 & 235.6 & 10.31 & 140.4 \\
\hline Atrazine @ 1 kg/ha pre-emergence & 7.38 & 0.20 & 0.35 & 235.1 & 10.23 & 140.3 \\
\hline $\begin{array}{l}\text { Pendimethalin @ 1 kg/ha pre- } \\
\text { emergence }\end{array}$ & 7.40 & 0.19 & 0.36 & 235.9 & 10.36 & 140.6 \\
\hline $\begin{array}{l}\text { Halosulfuron methyl @ 135 g/ha at } \\
\text { 15 DAS }\end{array}$ & 7.39 & 0.19 & 0.36 & 235.2 & 10.26 & 140.4 \\
\hline $\begin{array}{l}\text { 2 Hand weedings at 15 DAS and 30 } \\
\text { DAS }\end{array}$ & 7.37 & 0.20 & 0.35 & 233.4 & 10.07 & 140.2 \\
\hline Weedy check & 7.41 & 0.19 & 0.37 & 236.6 & 10.75 & 140.8 \\
\hline Weed free & 7.37 & 0.20 & 0.35 & 233.0 & 9.67 & 140.0 \\
\hline SEm ( \pm ) & 0.04 & 0.03 & 0.003 & 1.84 & 0.40 & 0.38 \\
\hline CD(p=0.05) & 7.3 & $\mathrm{~N} . \mathrm{S}$ & $\mathrm{N} . \mathrm{S}$ & $\mathrm{N} . \mathrm{S}$ & $\mathrm{N} . \mathrm{S}$ & $\mathrm{N} . \mathrm{S}$ \\
\hline Initial & 0.18 & 0.34 & 245.7 & 11.26 & 146.2 \\
\hline
\end{tabular}




\section{Int.J.Curr.Microbiol.App.Sci (2017) 6(6): 663-670}

Table.2 Effect of weed management practices on periodic N, P, K uptake by grain and stover in spring maize

\begin{tabular}{|c|c|c|c|c|c|c|c|c|c|c|c|c|c|c|c|}
\hline \multirow[b]{3}{*}{ Treatments } & \multicolumn{12}{|c|}{ Stover } & \multirow{2}{*}{\multicolumn{3}{|c|}{$\begin{array}{c}\text { Grain } \\
\text { At harvest }\end{array}$}} \\
\hline & \multicolumn{3}{|c|}{ At 30 DAS } & \multicolumn{3}{|c|}{ At 60 DAS } & \multicolumn{3}{|c|}{ At 90 DAS } & \multicolumn{3}{|c|}{ At harvest } & & & \\
\hline & $\underset{(\mathrm{kg} / \mathrm{ha})}{\mathrm{N}}$ & $\underset{(\mathrm{kg} / \mathrm{ha})}{\mathrm{P}}$ & $\begin{array}{c}\mathrm{K} \\
(\mathrm{kg} / \mathrm{ha})\end{array}$ & $\mathrm{N}(\mathrm{kg} / \mathrm{ha})$ & $\begin{array}{c}\mathrm{P} \\
(\mathrm{kg} / \mathrm{ha})\end{array}$ & $\begin{array}{c}\mathrm{K} \\
(\mathrm{kg} / \mathrm{ha})\end{array}$ & $\mathrm{N}(\mathrm{kg} / \mathrm{ha})$ & $\begin{array}{c}\mathrm{P} \\
\text { (kg/ha) }\end{array}$ & $\mathrm{K}(\mathrm{kg} / \mathrm{ha})$ & $\mathrm{N}(\mathrm{kg} / \mathrm{ha})$ & $\begin{array}{c}\mathrm{P} \\
(\mathrm{kg} / \mathrm{ha})\end{array}$ & $\begin{array}{c}\mathrm{K} \\
(\mathrm{kg} / \mathrm{ha})\end{array}$ & $\underset{(\mathrm{kg} / \mathrm{ha})}{\mathrm{N}}$ & $\begin{array}{c}\mathrm{P} \\
(\mathrm{kg} / \mathrm{ha})\end{array}$ & $\begin{array}{c}\mathrm{K} \\
(\mathrm{kg} / \mathrm{ha})\end{array}$ \\
\hline $\begin{array}{l}\text { Tembotrione @ } 110 \mathrm{~g} / \mathrm{ha} \text { at } 15 \\
\text { DAS }\end{array}$ & 18.89 & 13.56 & 36.52 & 21.22 & 13.12 & 39.27 & 21.76 & 15.25 & 45.82 & 20.38 & 14.74 & 45.64 & 37.40 & 7.87 & 8.38 \\
\hline $\begin{array}{l}\text { Tembotrione @110 g/ha at } 30 \\
\text { DAS }\end{array}$ & 1.32 & 5.51 & 9.24 & 20.54 & 13.06 & 39.15 & 21.40 & 15.15 & 45.66 & 20.19 & 14.62 & 45.49 & 37.08 & 7.93 & 8.41 \\
\hline $\begin{array}{c}\text { Tembotrione @ } 120 \mathrm{~g} / \mathrm{ha} \text { at } 15 \\
\text { DAS }\end{array}$ & 20.25 & 14.37 & 37.63 & 22.78 & 14.33 & 41.08 & 23.64 & 16.46 & 48.70 & 22.84 & 16.25 & 47.36 & 39.64 & 8.76 & 9.70 \\
\hline Tembotrione @ $120 \mathrm{~g} / \mathrm{ha}$ at $30 \mathrm{DA}$ & 1.31 & 5.52 & 9.25 & 22.46 & 14.18 & 40.95 & 23.32 & 16.37 & 48.67 & 22.52 & 16.15 & 47.01 & 39.32 & 8.66 & 9.67 \\
\hline $\begin{array}{l}\text { Tembotrione @ } 31 \mathrm{~g} / \mathrm{ha}+ \\
\text { atrazine @ } 370 \mathrm{~g} / \mathrm{ha} \text { at } 15 \mathrm{DAS}\end{array}$ & 17.04 & 12.69 & 34.87 & 19.33 & 11.84 & 37.29 & 19.56 & 13.67 & 41.64 & 17.78 & 13.18 & 44.16 & 34.50 & 7.09 & 7.47 \\
\hline $\begin{array}{c}\text { Atrazine @ } 1 \text { kg/ha pre- } \\
\text { emergence }\end{array}$ & 18.23 & 13.42 & 36.61 & 20.49 & 12.93 & 38.96 & 20.79 & 14.87 & 44.82 & 19.51 & 14.46 & 45.41 & 36.97 & 7.77 & 8.31 \\
\hline $\begin{array}{l}\text { Pendimethalin@ @ } 1 \text { kg/ha pre- } \\
\text { emergence }\end{array}$ & 15.58 & 12.04 & 32.69 & 17.82 & 10.89 & 34.21 & 18.37 & 12.49 & 39.61 & 16.03 & 12.03 & 42.86 & 33.14 & 6.46 & 6.78 \\
\hline $\begin{array}{c}\text { Halosulfuron methyl @ } 135 \\
\text { g/ha at 15 DAS }\end{array}$ & 17.09 & 12.82 & 34.92 & 19.42 & 12.01 & 37.41 & 19.68 & 13.93 & 42.31 & 17.95 & 13.31 & 44.23 & 35.51 & 7.12 & 7.54 \\
\hline $\begin{array}{l}2 \text { Hand weedings at } 15 \text { DAS } \\
\text { and } 30 \text { DAS }\end{array}$ & 20.10 & 14.16 & 37.33 & 22.17 & 14.04 & 40.78 & 22.79 & 16.24 & 48.10 & 21.99 & 15.89 & 46.84 & 38.79 & 8.57 & 9.10 \\
\hline Weedy check & 1.29 & 5.51 & 9.25 & 3.12 & 5.77 & 13.41 & 3.98 & 7.90 & 21.13 & 3.18 & 7.90 & 19.54 & 18.21 & 3.94 & 5.03 \\
\hline Weed free & 22.14 & 14.98 & 38.53 & 23.97 & 15.24 & 42.7 & 24.83 & 17.37 & 50.42 & 24.03 & 17.37 & 48.83 & 40.83 & 9.37 & 10.42 \\
\hline $\operatorname{SEm}( \pm)$ & 0.37 & 0.19 & 0.26 & 0.31 & 0.28 & 0.50 & 0.30 & 0.28 & 0.50 & 0.50 & 0.35 & 0.37 & 0.37 & 0.19 & 0.22 \\
\hline $\mathrm{CD}(\mathrm{p}=0.05)$ & 1.11 & 0.57 & 0.78 & 0.92 & 0.85 & 1.40 & 0.91 & 0.83 & 1.50 & 1.51 & 1.04 & 1.11 & 1.11 & 0.59 & 0.66 \\
\hline
\end{tabular}




\section{Int.J.Curr.Microbiol.App.Sci (2017) 6(6): 663-670}

Table.3 Effect of weed management practices on periodic N, P \& K uptake in weeds of spring maize

\begin{tabular}{|c|c|c|c|c|c|c|c|c|c|c|c|c|}
\hline \multicolumn{13}{|c|}{ Weeds } \\
\hline & \multicolumn{3}{|c|}{ At $30 \mathrm{DAS}$} & \multicolumn{3}{|c|}{ At 60 DAS } & \multicolumn{3}{|c|}{ At 90 DAS } & \multicolumn{3}{|c|}{ At harvest } \\
\hline Treatments & $\begin{array}{c}\mathrm{N} \\
(\mathrm{kg} / \mathrm{ha})\end{array}$ & $\begin{array}{c}\mathrm{P} \\
(\mathrm{kg} / \mathrm{ha})\end{array}$ & $\begin{array}{c}\mathrm{K} \\
(\mathrm{kg} / \mathrm{ha})\end{array}$ & $\begin{array}{c}\mathrm{N} \\
(\mathrm{kg} / \mathrm{ha})\end{array}$ & $\begin{array}{c}\mathrm{P} \\
(\mathrm{kg} / \mathrm{ha})\end{array}$ & $\begin{array}{c}\mathrm{K} \\
(\mathrm{kg} / \mathrm{ha})\end{array}$ & $\begin{array}{c}\mathrm{N} \\
(\mathrm{kg} / \mathrm{ha})\end{array}$ & $\begin{array}{c}\mathrm{P} \\
(\mathrm{kg} / \mathrm{ha})\end{array}$ & $\begin{array}{c}\mathrm{K} \\
(\mathrm{kg} / \mathrm{ha})\end{array}$ & $\begin{array}{c}\mathrm{N} \\
(\mathrm{kg} / \mathrm{ha})\end{array}$ & $\begin{array}{c}\mathrm{P} \\
\text { (kg/ha) }\end{array}$ & $\mathrm{K}(\mathrm{kg} / \mathrm{ha})$ \\
\hline Tembotrione@110 g/ha at 15 DAS & 4.85 & 1.37 & 5.02 & 9.61 & 3.32 & 9.72 & 6.97 & 2.97 & 7.32 & 6.05 & 1.76 & 5.95 \\
\hline Tembotrione @110 g/ha at 30 DAS & 9.32 & 3.21 & 12.83 & 9.74 & 3.48 & 9.86 & 7.02 & 3.04 & 7.36 & 6.09 & 1.81 & 5.99 \\
\hline Tembotrione @ $120 \mathrm{~g} / \mathrm{ha}$ at $15 \mathrm{DAS}$ & 3.76 & 0.62 & 4.13 & 7.09 & 2.13 & 8.14 & 5.31 & 1.23 & 5.73 & 4.98 & 0.97 & 4.97 \\
\hline Tembotrione @ $120 \mathrm{~g} / \mathrm{ha}$ at $30 \mathrm{DAS}$ & 9.41 & 3.23 & 12.32 & 7.97 & 2.36 & 8.31 & 5.86 & 1.26 & 6.16 & 5.12 & 0.95 & 5.14 \\
\hline $\begin{array}{l}\text { Tembotrione @ } 31 \mathrm{~g} / \mathrm{ha}+\text { atrazine } \\
\text { @ } 370 \mathrm{~g} / \mathrm{ha} \text { at } 15 \mathrm{DAS}\end{array}$ & 5.98 & 2.06 & 5.97 & 11.13 & 4.39 & 11.27 & 8.23 & 4.09 & 8.63 & 6.98 & 2.72 & 6.83 \\
\hline Atrazine@1 kg/ha pre-emergence & 5.14 & 1.49 & 5.12 & 9.92 & 3.79 & 10.16 & 7.17 & 3.12 & 7.41 & 6.12 & 1.89 & 6.04 \\
\hline $\begin{array}{l}\text { Pendimethalin@1 kg/ha pre- } \\
\text { emergence }\end{array}$ & 6.73 & 2.61 & 6.83 & 12.09 & 4.92 & 12.39 & 9.24 & 4.95 & 9.87 & 7.98 & 3.49 & 7.63 \\
\hline $\begin{array}{l}\text { Halosulfuron methyl @ } 135 \mathrm{~g} / \mathrm{ha} \text { at } \\
\text { 15 DAS }\end{array}$ & 5.86 & 2.04 & 5.84 & 10.86 & 4.31 & 11.14 & 8.19 & 3.97 & 8.59 & 6.92 & 2.65 & 6.78 \\
\hline $\begin{array}{l}\text { Hand weedings at } 15 \text { DAS and } 30 \\
\text { DAS }\end{array}$ & 3.94 & 0.79 & 4.31 & 8.69 & 2.86 & 8.75 & 5.89 & 1.98 & 6.19 & 5.29 & 0.99 & 5.26 \\
\hline Weedy check & 10.83 & 3.19 & 12.96 & 33.57 & 10.62 & 40.73 & 13.32 & 5.82 & 14.73 & 11.73 & 4.35 & 13.62 \\
\hline Weed free & 0.00 & 0.00 & 0.00 & 0.00 & 0.00 & 0.00 & 0.00 & 0.00 & 0.00 & 0.00 & 0.00 & 0.00 \\
\hline $\operatorname{SEm}( \pm)$ & 0.20 & 0.18 & 0.23 & 0.32 & 0.28 & 0.37 & 0.26 & 0.14 & 0.29 & 0.25 & 0.25 & 0.22 \\
\hline $\mathrm{CD}(\mathrm{p}=0.05)$ & 0.60 & 0.53 & 0.69 & 0.78 & 0.41 & 0.87 & 0.97 & 0.83 & 1.10 & 0.74 & 0.74 & 0.66 \\
\hline
\end{tabular}




\section{Periodic N, P and K uptake by stover of spring maize}

Nutrient uptake by stover in spring maize was greatly influenced by weed management treatments (Table 2). There was a profound increase in nutrient (NPK) uptake by maize crop due to weed management treatments as compared to weedy check plots. Among the weed management treatments, significantly highest NPK uptake by maize crop was recorded in the weed free plot over rest of the plots. Amongst the herbicidal treatments, significantly higher NPK uptake in stover was recorded with the post emergence application of tembotrione @120 g/ha at 15 DAS which was found to be at par with post emergence application of tembotrione @ $110 \mathrm{~g} / \mathrm{ha} 15$ DAS and 2 Hand weeding at 15 and 30 DAS. The possible reason for beneficial effect could possibly be attributed to higher weed-control efficiency with these treatments resulting in more favorable environment for growth and development of crop plants apparently due to lesser weed competition which led to increased growth of crop and thereby increase in nutrient uptake by improving the leaf area, dry matter accumulation leading to better yield attributes and accumulation of higher amounts of nutrients in maize grains. Similar findings were reported by Angiras and Singh (1989); Sreenivas and Satyanarayana (1996) and Mundra et al., (2002).

N, P and K uptake were recorded after 30, 60, 90 DAS and at harvest stage. A decreasing trend in $\mathrm{N}, \mathrm{P}$ and $\mathrm{K}$ uptake content was observed with the advancement of age of maize crop. Differential behavior in N, P and $\mathrm{K}$ uptake by maize could be ascribed to higher vegetative growth of winter maize resulting in higher $\mathrm{N}, \mathrm{P}$ and $\mathrm{K}$ concentration and in turn higher N, P, K uptake. Similar findings were reported by Kulkarni and Sojitra (1986) and Sinha et al., (2005).
Periodic N, P and $K$ uptake by weeds in spring maize

The removal of $\mathrm{N}, \mathrm{P}$ and $\mathrm{K}$ by weeds were reduced significantly by various herbicidal and manual weeding treatments and it was almost nil under weed free treatment whereas the significantly highest $\mathrm{N}, \mathrm{P}$ and $\mathrm{K}$ uptake by weeds were recorded in the weedy check treatment (Table 3). This might be attributed to luxuriant growth of unchecked weeds and weedy check plots which competed dominantly with the crop plants for nutrients. Similar findings were reported by Angiras and Singh (1989); Sreenivas and Satyanarayana (1996) and Mundra et al., (2002).

As there was no management of weeds in weedy check and weed population was highest, the nutrient uptake by weeds was also highest because weeds dominated the crop and ground was completely covered with weeds. The lowest uptake was recorded in herbicidal treatments as weeds were effectively controlled. These results are in conformity with Chalka and Nepalia (2006) and also with Balyan and Kumpawat (2008).

Amongst herbicidal treatments, significantly lowest values of $\mathrm{N}, \mathrm{P}$ and $\mathrm{K}$ uptake were recorded in post emergence application of tembotrione@120 g/ha at 15 DAS followed by post emergence application of tembotrione @ $110 \mathrm{~g} / \mathrm{ha} 15 \mathrm{DAS}$ and 2 hand weeding at 15 and 30 DAS whereas, significantly highest values of $\mathrm{N}, \mathrm{P}$ and $\mathrm{K}$ uptake by weeds were recorded with pendimethalin @ $1 \mathrm{~kg} / \mathrm{ha}$ as pre emergence which showed relatively lower efficacy against weeds whose infestation was predominantly higher in these plots but not to the extent observed in weedy check plots. It was also observed that wherever the removal of nutrients was higher due to weeds the corresponding uptake by crop plants was lower and vice-versa. N, P and K uptake were 
recorded after 30, 60, 90 DAS and at harvest stage. Maximum uptake by weeds was recorded at 60 DAS, this might be due to the fact that weeds imposed critical crop weed competition around 30-45 DAS and that leads compete at this period for uptake of nutrients.

\section{References}

Almsick, A.V., Buchholz, B.J., Olenik, B. and Willms, L. 2009. Tembotrione, a new exceptionally safe cross-spectrum herbicide for corn production. Bayer Crop Sci. J., 62(1): 5-16.

Angiras, N.N. and Singh, C.M. 1989. Economic analysis of integrated weed management in maize. Indian J. Weed Sci., 21(1): 29-36.

Balyan, J.K. and Kumpawat, B.S. 2008. Nutrient content and their uptake influenced by integrated nutrient management in maize. Int. J. Agri. Sci., 4(2): 453-456.

Chalka, M.K. and Nepalia, V. 2006. Production potential and economics of maize (Zea mays L.) intercropped with legumes as influence by weed control. Indian J. Agron., 5(2): 119-122.
Kulkarni, J.H. and Sojitra, V.K. 1986. Nodulation, growth, yield of groundnut under six intercropping system. Madras Agri. J., 73(7): 366-369.

Mishra, M. and Mishra, A. 1997. Estimation of integrated pest management index in Jute - A new approach. Indian J. Weed Sci., 29(1\&2): 39-42.

Mundra, S.L., Vyas, A.K. and Maliwal, P.C. 2002. Effect of weed and nutrient management on nutrient uptake by maize (Zea mays L.) and weeds. Indian J. Agron., 47(3): 378-383.

Raju, R.A. 1998. Prevalent weed flora in Peninsular India. Pp.57. New Delhi: Allied Publishers Pvt. Ltd. Agronomy, 44(1): 30-35.

Sinha, S.P., Prasad, S.M. and Singh, S.J. 2005. Nutrient utilization by winter maize (Zea mays L.) and weeds as influenced by integrated weed management. Indian J. Agron., 50(4): 303-304.

Sreenivas, G. and Satyanarayana, V. 1996. Nutrient removal by weeds and maize. Indian J. Agron., 41(1): 160-162.

\section{How to cite this article:}

Parveen Akhtar, Anil Kumar, Jai Kumar, Neetu Sharma, Lobzang Stanzen, Ashu Sharma and Amit Mahajan. 2017. Bio-Efficacy of Early Post and Post Emergent Application of Tembotrione on Nutrient Removal by Crop and Weeds in Spring Maize (Zea mays L.) Under Irrigated Sub-Tropical Shiwalik Foothill Conditions of J \& K. Int.J.Curr.Microbiol.App.Sci. 6(6): 663-670. doi: https://doi.org/10.20546/ijcmas.2017.606.078 